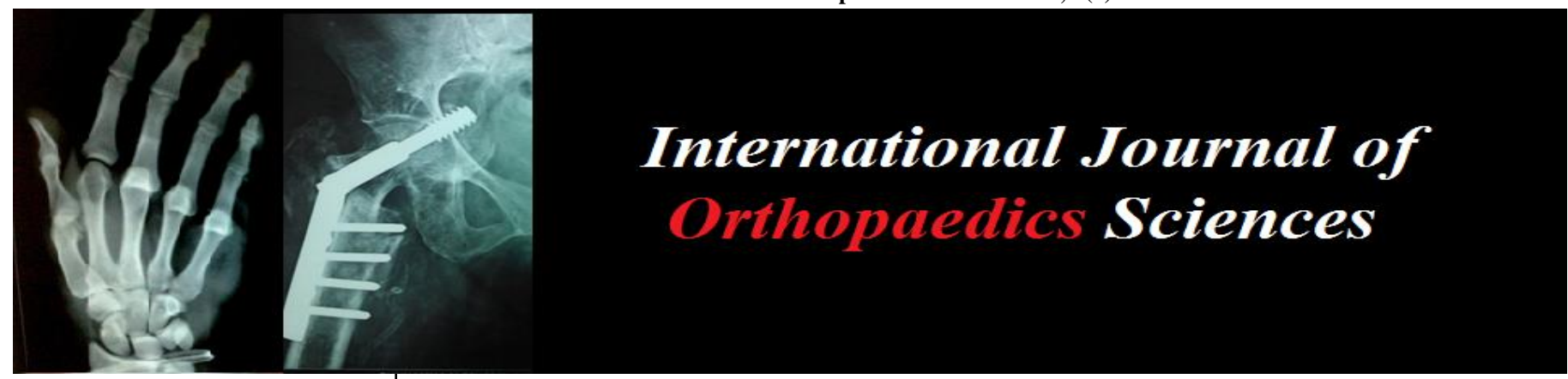

ISSN: $2395-1958$

IJOS 2019; 5(2): 951-953

(C) 2019 IJOS

www.orthopaper.com

Received: 24-02-2019

Accepted: 26-03-2019

Rakesh Kumar Misra

Associate Professor, Department

of Orthopaedics, Ananta

Institute of Medical Sciences,

Rajsamand, Rajasthan, India

\section{Ashish Batra}

Assistant Professor, Department

of Orthopaedics, Ananta

Institute of Medical Sciences,

Rajsamand, Rajasthan, India

\section{Hemant Khajja}

Senior Resident, Department of Orthopaedics, Ananta Institute of Medical Sciences, Rajsamand, Rajasthan, India

Kunal Raja

Senior Resident, Department of Orthopaedics, Ananta Institute of Medical Sciences, Rajsamand, Rajasthan, India

Correspondence

Rakesh Kumar Misra

Associate Professor, Department of Orthopaedics, Ananta

Institute of Medical Sciences,

Rajsamand, Rajasthan, India

\section{The role of body mass index (BMI), serum estrogen level and bone mineral density (BMD) in lumbar osteoarthritis and low back pain in postmenopausal women}

\section{Rakesh Kumar Misra, Ashish Batra, Hemant Khajja and Kunal Raja}

DOI: https://doi.org/10.22271/ortho.2019.v5.i2n.1462

Abstract

The present study aimed to assess the role of BMI, estrogen level and BMD in lumbar osteoarthritis and lower back pain in postmenopausal women.

Material and Methods: The present study is a prospective study carried out in the department of Orthopedics, Ananta Institute of Medical Sciences, Rajsamand, Rajasthan during the period of 1 year from April 2018 to April 2019. It includes 70 postmenopausal women, aged 50-75 years attended orthopaedic department with the complaint of low backache for at least 3 months. 70 premenopausal healthy women aged 25-45 years were also included in the study as control group. BMI, serum estrogen level and BMD were measured in both the groups and compared.

Results: Age of the patient's ranges from 50 to 75 years with the mean age of $62.9 \pm 5.6$ years. The average post-menopausal period was 8.7 years. Mean body mass index calculated was $26.3 \pm 1.6 \mathrm{~kg} / \mathrm{m}^{2}$ in postmenopausal group and was $24.1 \pm 1.2$ in controls. Mean estrogen level was $23.9 \pm 4.6 \mathrm{pg} / \mathrm{mL}$ in postmenopausal women and $141.8 \pm 11.6 \mathrm{pg} / \mathrm{mL}$ in controls. Mean Lumbar (L1-L4) bone mineral density was $0.856 \pm 0.181 \mathrm{~g} / \mathrm{cm}^{2}$ in postmenopausal group and $1.147 \pm 0.153 \mathrm{~g} / \mathrm{cm}^{2}$ in controls. Out of 70 patients, $61(87.14 \%)$ patients were having changes of lumbar OA in x-ray while 9 patients $(12.85 \%)$ were having normal lumbosacral $\mathrm{x}$-ray finding. None of the controls were having changes of osteoarthritis. Conclusion: Postmenopausal stage of life is associated with increased incidence of low back pain. Low estrogen level, Increased BMI and low BMD are the factors, significantly correlated with the occurrence of lumbar osteoarthritis and lower back pain in postmenopausal women

Keywords: Menopause, osteoarthritis, estrogen, back pain

\section{Introduction}

Menopause is permanent cessation of menstruation resulting in los of ovarian follicle development and subsequently decreases in ovarian production of hormone estrogen and progesterone ${ }^{[1,2]}$. The lower reproductive hormone production in menopause is associated with increased risk of osteoporosis, bone fractures and cardiovascular diseases. The age of menopause of an individual is genetically determined and is unaffected by her race, socioeconomic status, age at menarche, or number of prior ovulations. But there are various factors that can cause premature menopause or early menopause which include smoking, excessive alcohol consumption, damage to ovaries by radiotherapy/ chemotherapy or surgical removal of ovaries or hysterectomy ${ }^{[3,4]}$.

Hormonal changes that occur during menopause affect the occurrence of osteoarthritis. The process of degeneration of the spine, especially the lumbar area is called lumbar osteoarthritis (LOA). Menopause is associated with rapid bone loss, beginning 2-3 years before and continuing for up to 3-4 years after menopause ${ }^{[5]}$. This bone loss is usually manifested as significant decrease in bone mineral density (BMD) measured by dual energy X-ray absorptiometry (DEXA). (6) BMD is an important clinical measure of bone strength and health, and an association between reduced BMD and musculoskeletal pain is plausible. $(7,8)$ Musculoskeletal pain (9), and specifically lower back pain (LBP) (10-12), is one of the most common and consistently reported symptoms of postmenopausal women. 
Low back pain (LBP) restricts the mobility, interferes with normal functioning and affects the quality of life of not only affected women but also their family. Very few studies have been done till now, particularly in western part of India on LBP in postmenopausal women. With this regard, the present study aimed to assess the lower back pain and lumbar osteoarthritis in postmenopausal women and the role of BMI, estrogen level and BMD in LBP in postmenopausal women.

\section{Material and Methods}

Setting: The present study is a prospective study carried out in the department of Orthopedics, Ananta Institute of Medical Sciences, Rajsamand, and Rajasthan during the period of 1 year from April 2018 to April 2019.

\section{Type of study: Qualitative}

Study population: The present study includes 70 postmenopausal women, aged 50-75 years attended orthopaedic department with the complaint of low backache for at least 3 months.

\section{Inclusion criteria}

- Age $>50$ years $<75$ years

- Postmenopausal women with low backache symptoms

\section{Exclusion criteria}

- Premenopausal, perimenopausal women or women with uncertain menopausal status

- Women with osteoporotic fracture

- Women with rheumatoid arthritis

- Women with history of previous lumbar surgery in past 1 year

- Patients who did not gave consent for the study.

Weight, height, body mass index (BMI $\mathrm{kg} / \mathrm{m}^{2}$ ) and bone mineral density (BMD) of each individual were measured.
Blood sample of the cases also taken to check the estrogen level. X-ray lumbosacral region AP, Lateral and oblique view were also taken to diagnose and determine lumbar osteoarthritis status. Weight and height were measured by trained professionals and body mass index was calculated as weight in $\mathrm{kg} /$ height in meters ${ }^{[2]}$.

70 premenopausal healthy women aged $25-45$ years were also included in the study as control group. All the investigations including BMI, serum estrogen level and BMD were done in control group also and the results of both the group were compared.

\section{Results}

70 postmenopausal women were included in the study. Age of the patients ranges from 50 to 75 years with the mean age of $62.9 \pm 5.6$ years. The average post-menopausal period was 8.7 years. None of the patient was taking hormone replacement therapy.

70 healthy premenopausal women aged $25-45$ years were also included in the study as control group with the mean age of $33.8 \pm 4.6$ years.

The mean height and weight of the patients were 155.8 \pm 9.8 $\mathrm{cm}$ and $59.7 \pm 6.2 \mathrm{~kg}$ respectively while in control group the mean height and weight were $156.9 \pm 8.8$ and $55.4 \pm 6.6$ respectively.

Mean body mass index was $26.3 \pm 1.6 \quad \mathrm{~kg} / \mathrm{m}^{2}$ in postmenopausal group and was $24.1 \pm 1.2$ in controls.

Mean estrogen level was $23.9 \pm 4.6 \mathrm{pg} / \mathrm{mL}$ in postmenopausal women while in control group the estrogen level was $141.8 \pm 11.6 \mathrm{pg} / \mathrm{mL}$.

Mean Lumbar (L1-L4) bone mineral density was $0.856 \pm 0.181$ $\mathrm{g} / \mathrm{cm}^{2}$ in postmenopausal group and $1.147 \pm 0.153 \mathrm{~g} / \mathrm{cm}^{2}$ in controls.

Out of 70 patients, $61(87.14 \%)$ patients were having changes of lumbar OA in $\mathrm{x}$-ray while 9 patients $(12.85 \%)$ were having normal lumbosacral $\mathrm{x}$-ray finding. None of the controls were having changes of osteoarthritis.

Table 1: Comparison of variables in cases and controls

\begin{tabular}{|c|c|c|c|}
\hline S. No. & Variables (Mean \pm SD) & Value in postmenopausal women & Value in premenopausal control group \\
\hline 1. & Age $($ years $)$ & $62.9 \pm 5.6$ & $33.8 \pm 4.6$ \\
\hline 2. & Height $(\mathrm{cm})$ & $155.8 \pm 9.8$ & $156.9 \pm 8.8$ \\
\hline 3. & Weight $(\mathrm{Kg})$ & $59.7 \pm 6.2$ & $55.4 \pm 6.6$ \\
\hline 4. & BMI $\left(\mathrm{kg} / \mathrm{m}^{2}\right)$ & $26.3 \pm 1.6$ & $24.1 \pm 1.2$ \\
\hline 5. & Estrogen level $(\mathrm{pg} / \mathrm{mL})$ & $23.9 \pm 4.6$ & $141.8 \pm 11.6$ \\
\hline 6. & BMD L $1-\mathrm{L}_{4}\left(\mathrm{~g} / \mathrm{cm}^{2}\right)$ & $0.856 \pm 0.181$ & $1.147 \pm 0.153$ \\
\hline 7. & Lumbar OA $(\%$ of cases $)$ & $87.14 \%$ & None \\
\hline
\end{tabular}

\section{Discussion}

70 postmenopausal women with the complaints of low back ache were included in the study and 70 premenopausal healthy women were taken as controls.

The age of the patients ranges from 50 to 75 years with the mean age of $62.9 \pm 5.6$ years. The average post-menopausal period was 8.7 years.

There was significant difference between the values of BMI, estrogen level and BMD in postmenopausal cases and premenopausal controls. Mean body mass index was $26.3 \pm 1.6$ $\mathrm{kg} / \mathrm{m}^{2}$ in postmenopausal group and was $24.1 \pm 1.2$ in controls. Mean estrogen level was $23.9 \pm 4.6 \mathrm{pg} / \mathrm{mL}$ in postmenopausal women while in control group the estrogen level was $141.8 \pm 11.6 \mathrm{pg} / \mathrm{mL}$.

Mean Lumbar (L1-L4) bone mineral density was $0.856 \pm 0.181$ $\mathrm{g} / \mathrm{cm}^{2}$ in postmenopausal group and $1.147 \pm 0.153 \mathrm{~g} / \mathrm{cm}^{2}$ in controls.
These findings support a number of previous studies done on BMD, BMI and estrogen level in menopause.

Tomotaka Akatsu carried out a study on sex steroids, bone turnover and BMD in pre- $(n=18)$, peri- $(n=18)$ and postmenopausal women $(n=52)$. They concluded that estrogen deficiency in postmenopausal period was associated with increased bone resorption and decreased BMD ${ }^{[14]}$.

Carolin J Crandall et al performed a study on serum sex steroid level and longitudinal changes in bone density in relation to the final menstrual period. They concluded that Higher Estrogen levels and lower FSH levels were associated with lower rates of LS (lumbar spine) bone loss in some but not all menopausal transition phases ${ }^{[15]}$.

Matthews KA et al studied BMI in mid-life women and found that postmenopausal women had higher BMI when compared to pre-menopausal women. The results favor the result of present study ${ }^{[16]}$. 
Lower back pain in postmenopausal women is the most common clinical manifestation of the degeneration process over the main segment of the spine that are most mobile lumbar segments ${ }^{[17,18]}$.

In present study, out of 70 patients, $61(87.14 \%)$ patients were having changes of lumbar OA in radiological findings while 9 patients $(12.85 \%)$ were having normal lumbosacral x-ray finding. None of the controls were having changes of osteoarthritis.

I. ketut Suyasa, in the year 2016 studied the role of ageing, BMI and estrogen on symptomatic lumbar osteoarthritis in 196 postmenopausal women. They found that 186 patients were having lumbar OA and 106 patients were symptomatic with low back pain. They concluded that these variables were significantly correlated with the incidence of symptomatic lumbar OA ${ }^{[19]}$.

Finally we conclude that all postmenopausal women with low back pain should be investigated completely with serum estrogen level, BMD, BMI and radiological tests for osteoarthritis. These cases should be managed with hormone replacement therapy, anti-inflammatory drugs and physiotherapy.

The limitations of present study in addition to modest sample size were that the women included in present studies were from the rural area near the institute. The results obtained may not be generalized to women of other/ urban areas. Second, the results were not reassessed after the treatment of the disorder, which may affect the results and provide additional information.

\section{Conclusion}

Postmenopausal stage of life is associated with increased incidence of low back pain. Low estrogen level, Increased BMI and low BMD are the factors increasing the prevalence of pain. The result of present study suggested that these factors are significantly correlated with the occurrence of lumbar osteoarthritis and lower back pain in postmenopausal women. Future research are expected which includes larger sample population and more risk factors to gain more accurate results and further information.

\section{Informed consent}

Well informed and written consent was taken from all the participants included in the study.

\section{References}

1. Sherwin B Menopause Myths, realities. Psychological aspects of women's health care. In: Stotland NL, Stewart DE editors. The Interface between Psychiatry and Obstetrics and Gynecology. Arlington: American Psychiatric Publishing, 2001, 241-59.

2. Spinelli MG Depression, hormone therapy. Clin Obstet Gynecol. 2004; 47:428-36. [PubMed: 15166869]

3. Adena MA, Gallagher HG. Cigarette smoking and the age at menopause. Ann Hum Biol. 1982; 9:121-30. [PubMed: 7081945]

4. Siddle N, Sarrel, $P$ Whitehead M. The effect of hysterectomy on the age at ovarian failure: Identification of a subgroup of women with premature loss of ovarian function and literature review. Fertil Steril. 1987; 47:94100. [PubMed: 3539646]

5. Recker R, Lappe J, Davies K, Heaney R. Characterization of peri-menopausal bone loss: a prospective study. J Bone Miner Res. 2000; 15:19651973.
6. Gallager JC Effect of early menopause on bone mineral density and fractures. Menopause. 2007; 14:567-571.

7. Gaber TA-ZK, McGlashan KA, Love S, Jenner JR, Crisp AJ. Bone density in chronic low back pain: a pilot study. Clin Rehabil. 2002; 16:867-870.

8. Briggs AM, Straker LM, Wark JD. Bone health and back pain: what do we know and where should we go? Osteoporos Int. 2009; 20:209-219.

9. Freeman EW, Sammuel MD, Lin H, Gracia CR, Pien GW, Nelson DB et at. Symptoms associated with menopausal transition and reproductive hormones in midlife women. Obstet Gynecol 1. 2007; 10:230-240.

10. Adera T, Deyo RA, Donatelle, RJ Premature menopause and low back pain. A population-based study. Ann Epidemiol. 1994; 4:416-422.

11. Dugan SA, Powell LH, Kravitz HM, Everson Rose SA, Karavolos K, Luborsky $\mathrm{J}$ musculoskeletal pain and menopausal status. Clin J Pain. 2006; 22:325-331.

12. Manabe T, Takasugi SI, Iwamoto Y. Positive relationship between bone mineral density and low back pain in middle-aged women. Eur Spine J. 2003; 12:596-601.

13. Sievert LL, Goode-Null SK. musculoskeletal pain among women of menopausal age in Puebla, Mexico. J Cross Cult Gerontol. 2005; 20:127-140.

14. Tomotaka AKATSU Sex steroid, bone turnover and BMD in pre-, peri- and postmenopausal women. Environmental Health and Preventive Medicine. 1998; 3:123-129.

15. Carolina J Crandall et al. serum sex steroid level and longitudinal changes in bone density in relation to the final menstrual period. The Journal of Clinical Endocrinology \& Metabolism. 2013; 98(4):E654-E663, https://doi.org/10.1210/jc.2012-3651.

16. Matthews KA, Abrams B, Crawford S, Miles T, Neer R, Powell LH, et al. Body mass index in mid-life women: relative influence of menopause, hormone use, and ethnicity. Int J Obes Metab Disord. 2001; 25(6):863-73.

17. Wong DA, Transfeldt E. Macnab's Backache. Fourth Edition. Philadelphia: Lippincot Williams \& Wilkins. 2007, 166-224.

18. Goode AP, Carey TS, Jordan JM. Low back pain and lumbar spine osteoarthritis: how are they related? Curr Rheumatol Rep. 2013; 15:305.

19. Ketut Suyasa GN, Yudhi Setiawan. The role of ageing, body mass index and estrogen on symptomatic lumbar osteoarthritis in postmenopausal women. Int J Res Med Sci. 2016; 4(5):1325-1328. 